1

2

3

4

5

6

7

8

9

10

11

12

13

14

15

16

17

18

19

20

21

22

23

24

\section{Sex Determination in the garden lizard, Calotes versicolor: Is Environment a} Factor?

Priyanka $^{1}$ and Rajiva Raman ${ }^{1,2}$

${ }^{1}$ Cytogenetics Laboratory, Department of Zoology, Banaras Hindu University, Varanasi-221005,

${ }^{2}$ Corresponding Author: E-mail: rajiva.raman@gmail.com

Orcid Identifier: 0000-0002-6043-4439

Priyanka and R. Raman: Unisex offspring in the lizard C. versicolor 


\section{Abstract}

27 Ganesh et al 1997). A report from the tropical southern India (Inamdar et al., 2012), claims a

28 TSD (FMFM) mechanism in this species in which the male/female ratio in embryos oscillates

29 within a range of $3-4^{0} \mathrm{C}$. The present study presents results of experiments done in 4 consecutive

30 breeding seasons of $C$. versicolor belonging to the subtropical/temperate climate of northern

31 region of India. Eggs were grown at different temperatures (at 24.5/28/31.5 $\mathrm{C}$ ) or under

32 seminatural conditions. Another set of eggs was exposed to fadrozol, an aromatase inhibitor (AI),

33 or Lithium Chloride (inhibitor of GSK3 enzyme inducing Wnt4-dependent Beta-Catenin).

34 Results confirm our earlier finding that in this subtropical population of C. versicolor,

35 temperature does not regulate gonadal differentiation but AI-induces sex reversal to the male sex

36 (Ganesh and Raman, 1995, Ganesh et al 1999). We also report lack of any effect of Sox9

37 inhibitor on sexual differentiation which may be due to inadequate quantity or mode of

38 application. Importantly, we report the serendipitous observation that in each year almost all the

39 embryos/hatchlings were of the same sex (females in 2013, '15, '16 and males in 2014)

40 regardless of the rearing condition and duration of incubation. Obviously, parthenogenesis is not

41 the cause of it. In the absence of an obvious reason to explain this pattern, we surmise that in this

42 north Indian population of $C$. versicolor, female is the default sex, and certain epigenetic

43 regulators could modulate the sexual differentiation of the individual. 


\section{Introduction}

46 Calotes versicolor is a common garden lizard distributed throughout south-east Asia, and

47 prevalent in the Indian subcontinent. Male and females are easily distinguishable by virtue of the

48 dorsal crest and hemipenis in the male, but chromosomally the two sexes are identical (Singh

49 1974, Ganesh et al.1997). Also, the embryos grown at different temperatures do not indicate

50 TSD (Ganesh and Raman, 1995). Thus, prima facie, C. versicolor lacks both CSD

51 (Chromosomal Sex Determination) and TSD (Temperature Sex Determination), the two common

52 modes of sex determination in reptiles, including lizards. However, treatment of growing eggs

53 with androgens, the male gonad hormones, lead to all male progeny, especially with DHT,

54 though the treatment with estradiol has no affect on the sex (Ganesh and Raman 1995, Ganesh et

55 al 1999). Contrary to our results, a recent study on the same species from southern India shows a

56 rather intricate TSD mechanism (Inamdar et al 2012). Using 14 different temperatures ranging

57 from $23.5 \pm 0.5^{\circ} \mathrm{C}$ to $35 \pm 0.5^{0} \mathrm{C}$ for egg incubation, the authors found all female progeny at low of

$58 \quad 23.5$ and high of $31.5 \pm 0.5^{\circ} \mathrm{C}$ and all male progeny at 25.5 and $34^{\circ} \mathrm{C}$. The sex ratio was even at

$5924.5,28.5$ and $33^{\circ} \mathrm{C}$, implying that between temperatures the sex ratio fluctuated through female-

60 male-female-male (FMFM), and that there is TSD in this species.

61 We have re-examined sex ratios in the local population of $C$. versicolor under different

62 incubation conditions including temperature. We did not find association of sex ratio with

63 temperature, instead an unanticipated set of results in the delivery of single sex progeny in

64 successive breeding seasons were observed. We present the results in this paper. 

lawns, and feeds on small insects. Not being an endangered species, there are no specific restrictions on their collection from the wild. It is a seasonal breeder with prolific reproductive activity during monsoon. However, they are not easily amenable to captive breeding. performed, is situated in the eastern zone of north India (latitude north: $25^{0} 8^{\prime}$; longitude east: $83^{0}$ 1'), and experiences subtropical climate with reasonably cold winters and strong summers, intervened by monsoon rains between the end of June and mid-September which induces reproductive activity in the lizard. Therefore each year during this period, a fresh lot of animals were collected from the wild (forests around $20 \mathrm{kms}$ away from the University campus), and brought to the lab. All applicable international, national and/or institutional guidelines for the care and use of animal were followed. Following 2-3 days of acclimatization in wooden cages, 10-12 gravid females were guillotined for collection of eggs (a clutch 12-20 eggs per individual) and other tissues. The eggs were placed in earthen pots having sterile sand, and - barring one

81 group that was placed in a bush 200 meters away from the lab - all others were maintained in

82 BOD incubators at different temperatures $\left(28^{0} \mathrm{C} / 31.5^{\circ} \mathrm{C} / 24.5^{\circ} \mathrm{C}\right.$ all $\left.\pm 0.5^{0} \mathrm{C}\right)$. Fadrozole

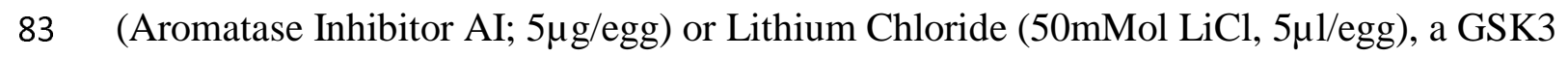

84 inhibitor that activates $\beta$ Catenin resulting in silencing of Sox9 (Bernard et al., 2012), were topically applied to certain eggs on day 6 of incubation. Water was sprinkled every morning and evening in the pots, to maintain humidity. Diurnal weather charts of the University campus were

87 obtained from the Meteriological Department in the University. Mesonephros Gonadal complex (MGC) of certain embryos and hatchlings were fixed in Bouin and preserved for gonadal

$$
\text { histology. Tissue sections were stained with haematoxylene. }
$$


Since embryonic gonads in this species, retained the testis and ovarian remnants until

91 hatching, embryonic sex was deciphered only late in development through presence $\left(\mathrm{Hp}^{+}\right)$or

92 absence $\left(\mathrm{Hp}^{-}\right)$of hemipenis $(\mathrm{Hp})$ that emerges in all the embryos by about day 30 but regresses

93 in putative females latest by day 40 .

The study was done in 4 consecutive breeding seasons (2013 - 2016), and different types

of experiments were set up in different years with the objective of finding the sex of individuals

97 grown under those conditions (temperature, quasi-natural, and gonadal enzyme inhibitors). We

98 present the results year-wise, as they were obtained, because each year guided the experiments

99 for the following year (see Table 1).

100 In the year 2013 , the eggs were incubated at $31.5^{\circ} \mathrm{C}$ (expected $100 \%$ ) $)$ and $28^{0} \mathrm{C}(\hat{\delta} / q 50 \%$ each; standard temperature). In addition, certain eggs were topically applied fadrozol (Aromatase Inhibitor, $\mathrm{AI}$ ) or $\mathrm{LiCl}$ (Lithium chloride) on day 6 ( at $28^{0} \mathrm{C}$ ). Each group comprised at least 10 eggs. Embryos were sacrificed mostly between days 41 and 43 of development, and checked for presence or absence of hemipenis (Hp).

107 The results show (Table 1) that while $\sim 90 \%$ of the AI-treated eggs were $\mathrm{Hp}^{+}$, the $\mathrm{LiCl}$ and the $108 \quad 31.5^{\circ} \mathrm{C}$ embryos were all $\mathrm{Hp}^{-}$. This result was on the expected line except for the fact that the $28^{0} \mathrm{C}$ (control) embryos also were all $\mathrm{Hp}^{-}$when they were expected to be a mix of $\mathrm{Hp}^{+}$and $\mathrm{Hp}^{-}$ 110 embryos. Thus barring the AI treated embryos $\left(14 \delta^{\lambda}: 2 q\right)$, most others were females $\left(53 q: 2 \delta^{\lambda}\right)$.

111 We repeated the AI and LiCl-treatments in the next breeding season (year 2014). This year, 112 while the AI-treated eggs were all $\mathrm{Hp}^{+}\left(8 \delta^{\top}: 0\right.$ 우), those treated with $\mathrm{LiCl}$ and the controls $\left(28^{0} \mathrm{C}\right)$ 
113 too were $\mathrm{Hp}^{+}\left(33 \hat{\sigma}^{\wedge}: 0\right.$ + $)$, unlike in 2013 when they were females. Clearly, AI-treatment led to

114 reversal of sex towards male in both the years as shown earlier (Ganesh et al 1999). In contrast,

$115 \mathrm{LiCl}$ results were identical to the controls in both the years. Apparently LiCl did not affect

116 gonadal differentiation, possibly either because of the embryonic stage at which it was

117 administered or due to the mode of application or else because of inadequate concentration. Thus

118 in both the years barring the AI-treated, almost all the embryos were of one sex, regardless of the

environment. However, two precociously gravid females caught in the first week of June

120 (ambient temp. $\sim 45^{\circ} \mathrm{C}$, when gravid females are rarely seen), and had just 7 and 5 eggs, yielded 4

$121 \mathrm{Hp}^{+}$and $8 \mathrm{Hp}^{-}$embryos.

In the next breeding season (year 2015), embryos were incubated at $24.5^{\circ} \mathrm{C}$ or $31.5^{\circ} \mathrm{C}$.

123 Another bunch of eggs was placed in a bush some 200 meters away from the lab, in earthen pots

124 in sterile sand, covered with a fine net (quasi-natural condition). They were thus exposed to

125 diurnal fluctuations of temperature $\left(7-10^{\circ} \mathrm{C}\right.$ - between 37 and $\left.22^{\circ} \mathrm{C}\right)$, humidity, day-night length

126 etc. In another variation to the protocol, only 14 bush grown and 10 controls were sacrificed as

127 embryos on days $43 \& 44$, rest were allowed to grow full term to hatch so that the sex could be

128 confirmed unambiguously in the hatchlings by examining the Hp and the gonadal histology. The

129 bush-grown embryos hatched between days $47-48$ while those reared at $31.5^{0} \mathrm{C}$ hatched on days

130 55-56. Each embryo and hatchling was $\mathrm{Hp}^{-}$. Gonadal sections of hatchlings or embryos observed

131 under microscope displayed growing ova and no sex cords, confirming their ovarian nature (Fig.

132 1). The $24.5^{\circ} \mathrm{C}$ embryos did not hatch until much later. Therefore we dissected 7 of them on day

13366 , which developmentally compared to the $30-35$ day old $28^{0} \mathrm{C}$ embryos. They, as expected of

134 embryos at that stage, had rudimentary Hps. The 2 embryos dissected on day 80 (comparable to

135 day 40 embryo at $28^{\circ} \mathrm{C}$ ), and the one that hatched on day 86 were rather weak but all of them 
136

137

138

139

140

141

142

143

144

145

146

147

148

149

150

151

152

153

154

155

156

157

158

were lacked Hp. Considering that all other embryos and hatchlings were females, we inferred that the $24.5^{0} \mathrm{C}$-day $66-\mathrm{Hp}^{+}$embryos to be females too. But even if we exclude them as ambiguous, there were 56 females against 00 males, irrespective of the environment they grew. The same was the condition in 2016 where embryos were grown at 28 or $31.5^{\circ} \mathrm{C}$. Those kept at $28^{\circ} \mathrm{C}$ were dissected serially on days $37,39,41,44$ and $47(6$ each $n=30)$ with the objective of catching the period when rudimentary Hemipenis that emerged around day 30 of development atrophied in prospective female embryos, but all of them, even those of day 37 , turned out to be $\mathrm{Hp}^{-}$. Of the $31.5^{\circ} \mathrm{C}$ lot, all 4 the embryos were $\mathrm{Hp}^{-}$, but of the 5 hatchlings were $\mathrm{Hp}^{-}$as against 3 $\mathrm{Hp}^{+}$hatchlings.

Data on the diurnal climatic conditions in and around the University campus during these 4 ywars were obtained from the Materiological Department. As expected, June was the hottest and the driest month, up to the third week, in all the 4 years. A comparison of the mean of minimum, maximum and the diurnal range of temperatures and relative humidity between June and August, showed no difference in the 4 years except that the rain fall was the lowest in 2014 $(593 \mathrm{~mm})$ and maximum in $2016(962 \mathrm{~mm})$. There were only 27 days of rain in 2014, the year in which all the embryos were males (Table 2).

Thus the present set of experiments done over a period of 4 years, exposing eggs to different regimes of constant temperatures as well as quasi-natural conditions in which environment fluctuated diurnally, give no reason to suspect Temperature or Environment dependent sex determination (TSD/ESD) mechanism in this population of $C$. versicolor. Therefore the only way to reconcile the present results with that of Inamdar et al (2012) would be the different climatic conditions the two populations live in; the prolonged breeding season and no exposure to extreme climatic in tropical environs of southern India differing from their 
north Indian morph. The present results however have added complexity insofar that all the progeny are of the same sex in consecutive 4 years. It is particularly strange because we have not recorded similarly skewed sex ratio in the previous 15 years. Independent of us, there is at least one report on the sex ratio of the lab-born hatchlings of this species from this region for the calendar years 1964-1966 which recorded 159 males to 100 females (Pandha and Thapliyal, 1967).

Naturally occurring skewed sex ratios and sex reversals are not uncommon in animal kingdom, more specifically in reptiles. In fact they are considered a source of ongoing evolution of sex determining mechanisms (Holleley et al., 2015). However, birth of only one sex individuals in nature is rare except due to parthenogenesis (Maslin, 1971). In sexually reproducing species, parthenogenesis is noticed in populations recording absence of males, but that seems improbable in this species because of the natural cohabitation of males and females in this population, and also because of birth of all male progeny in 2014. Several other reasons/mechanisms of skewed sex ratio in reptilian populations have been shown, largely drawn from the skewed ratio in adult populations (Charnov, 1982; Trivers \& Willard 1973; West et al., 2002). There are also examples of prefertilisation adaptation towards the sex ratio of the offspring depending upon the accumulation of the gonadal hormones in yolk during maturation of egg (Radder, 2007). Besides environmental factors, examples of the lizards, Ctenophorus pictus and Anolis sagrei allude to a genetic mechanisms responsible for skewed sex ratio (Olsson et al., 2007, Cox \& Calsbeek, 2010)..

Previous studies from our lab had shown lack of TSD in C. versicolor, but they also showed androgen-induced unilateral sex reversal towards male progeny (Ganesh and Raman 1995). Therefore, we had surmised that sex determination in C. versicolor is under weak genetic 
182 regulation which could be superseded by hormonal interventions. We also proposed that female

183 is the default sex in C. versicolor whose fate is fixed later than that of male during development,

184 and if the male pathway genes are switched on or induced (say, by androgens) earlier than the

185 fixation of the female pathway, the individuals would develop into males (Ganesh et al 1999,

186 Chakraborty and Raman 2010). Even though at present there is no obvious and cogent

187 explanation to the unisex progeny reported here, it does lead to a possibility that the reason for

188 the default nature of the female sex could be due to accumulation of gonadal hormones in the

189 egg yolk or imprinting of certain loci in the gametes which could control the sex ratio of the

190 embryo, possibly in response to population dynamics and/or prevailing environment. We record

191 this novel observation in this widely distributed species so that future investigations on this

192 species take into account occasional extreme skewing of sex ratios.

193 Acknowledgements: This work was supported by grants from the Department of Science \& Technology

194 and later by the Council of Scientific \& Industrial Research, New Delhi under the Scientist Emeritus

195 scheme no. 21(0946)/13/EMR-II to RR. Priyanka thanks CSIR for her Junior and Senior Research

196 Fellowships. 


\section{References:}

Bernard P, Ryan J, Sim H,. Czech DP, Sinclair AH, Koopman P, Harley VR (2012) Wnt signaling in ovarian development inhibits Sf1 activation of Sox9 via Tesco Enhancer. Endocrinology 153:901-912.

Chakraborty A. Raman R (2010) Modulation of gene activity in androgen-induced sex reversal in the garden lizard, Calotes versicolor. Sexual Dev 4, 162-169.

Charnov EL(1982) The theory of sex allocation. Princeton University Press, Princeton.

Cox RM, Calsbeek R (2010) Cryptic sex-ratio bias provides indirect genetic benefits despite sexual conflict. Science 328:92-94.

Ganesh S, Raman R (1995). Sex reversal by testosterone and not by estradiol or temperature in Calotes versicolor; the lizard lacking sex chromosomes. Journal of Experimental Zoology 271:139-144.

Ganesh S, Mohanty J, Raman R (1997) Male biased distribution of the human Y chromosomal genes SRY and ZFY in the lizard, Calotes versicolor, which lacks sex chromosomes and temperature dependent sex determination. Chrom Res 5: 413-419.

Ganesh S, Choudhary B, Raman R (1999). Temporal difference between testis and ovary determinations with possible involvement of testosterone and aromatase in gonadal differentiation in TSD lacking lizard, Calotes versicolor. J Exp Zool 283:600-607.

Holleley C. E., O’Meally D, Sarre SD, Graves JAM, Ezaz T, Matsubara K, Azad B, Zhang X, and Georges A (2015) Sex reversal triggers the rapid transition from genetic to temperaturedependent sex. Nature 523:79-81. 
219 Inamdar LS, Vani V, Seshagiri PB (2012) A tropical oviparous lizard, Calotes versicolor,

220 exhibiting a potentially novel FMFM pattern of temperature dependent sex determination. $\mathbf{J}$

$221 \quad$ Exp Zool 317:32-46.

222 Maslin TP (1971) Parthenogenesis in reptiles. American Zoologist 11:361-380.

223 Olsson M, Shine R (2001) Facultative sex allocation in snow skink lizards (Niveoscincus

224 microlepidotus). J Evol Biol 14:120-128.

225 Pandha SK, Thapliyal JP (1967) Egg laying and development in the garden lizard, Calotes

226 versicolor. Copiea 1967:121-125.

227 Radder RS (2007) Maternally derived egg yolk steroid hormones and sex determination: Review

228 of a paradox. J Biosci 32:1213-1220.

229 Singh L (1974) Study of mitotic and meiotic chromosomes in seven species of lizards. Proc Zool

$230 \quad$ Soc Calcutta 27:57-79 .

231 Trivers RL, Willard DE (1973) Natural selection of parental ability to vary the sex ratio of

$232 \quad$ offspring. Science 179:90-92.

233 West SA, Reece SE, Sheldon BC (2002) Sex ratios, Heredity 88:117-124. 
235 Table 1. Year-wise details of the embryos/hatchlings with and without hemipenis (Hp) under 236 different experimental conditions

\begin{tabular}{|c|c|c|c|c|c|c|c|}
\hline Year & $\begin{array}{l}\text { Incu. } \\
\text { Temp }\end{array}$ & Treatment & $\begin{array}{l}\text { Total } \\
\text { eggs }\end{array}$ & $\begin{array}{l}\text { Eggs } \\
\text { Survived }\end{array}$ & $\begin{array}{l}\text { Day } \\
\text { sacrificed }\end{array}$ & $\mathrm{Hp}^{+}$ & $\mathrm{Hp}^{-}$ \\
\hline \multirow[t]{3}{*}{2013} & $28^{\circ} \mathrm{C}$ & $\begin{array}{l}\text { Fadrozol (5ug/egg) } \\
\text { Control }\end{array}$ & $\begin{array}{l}17 \\
11\end{array}$ & $\begin{array}{l}16 \\
11\end{array}$ & $\begin{array}{l}42 \\
42\end{array}$ & $\begin{array}{l}14 \\
00\end{array}$ & $\begin{array}{l}2 \\
11\end{array}$ \\
\hline & $28^{\circ} \mathrm{C}$ & $\begin{array}{l}\mathrm{LiCl}(50 \mathrm{mM} ; 5 \mathrm{ul} / \mathrm{egg}) \\
\text { Control }\end{array}$ & $\begin{array}{l}15 \\
16\end{array}$ & $\begin{array}{l}14 \\
16\end{array}$ & $\begin{array}{l}41 \\
41\end{array}$ & $\begin{array}{l}01 \\
00\end{array}$ & $\begin{array}{l}13 \\
16\end{array}$ \\
\hline & $31.5^{\circ} \mathrm{C}$ & High temperature & 15 & 15 & 40 & 1 & 14 \\
\hline \multirow[t]{2}{*}{2014} & $28^{\circ} \mathrm{C}$ & $\begin{array}{l}\text { Fadrozol (5ug/egg) } \\
\text { Control }\end{array}$ & $\begin{array}{l}10 \\
10\end{array}$ & $\begin{array}{l}08 \\
09\end{array}$ & $\begin{array}{l}42 \\
42\end{array}$ & $\begin{array}{l}08 \\
09\end{array}$ & $\begin{array}{l}00 \\
00\end{array}$ \\
\hline & $28^{\circ} \mathrm{C}$ & $\begin{array}{l}\mathrm{LiCl}(50 \mathrm{mM} ; 5 \mathrm{ul} / \mathrm{egg}) \\
\text { Control }\end{array}$ & $\begin{array}{l}11 \\
13\end{array}$ & $\begin{array}{l}11 \\
13\end{array}$ & $\begin{array}{l}41 \\
41\end{array}$ & $\begin{array}{l}11 \\
13\end{array}$ & $\begin{array}{l}00 \\
00\end{array}$ \\
\hline \multirow[t]{4}{*}{2015} & ambient & In a bush in nature & 35 & 31 & $\begin{array}{l}43 \\
44 \\
\text { hatchling }\end{array}$ & $\begin{array}{l}00 \\
00 \\
00\end{array}$ & $\begin{array}{l}10 \\
04 \\
13\end{array}$ \\
\hline & $31.5^{\circ} \mathrm{C}$ & High temperature & 10 & 10 & hatchling & 00 & 10 \\
\hline & $28^{\circ} \mathrm{C}$ & Control & $\begin{array}{l}10 \\
07\end{array}$ & $\begin{array}{l}09 \\
07\end{array}$ & $\begin{array}{l}43 \\
\text { hatchllng }\end{array}$ & $\begin{array}{l}00 \\
00\end{array}$ & $\begin{array}{l}09 \\
07\end{array}$ \\
\hline & $24.5^{\circ} \mathrm{C}$ & Low temperature & 14 & 10 & $\begin{array}{l}66 \\
80 \\
\text { hatchling }\end{array}$ & $\begin{array}{l}07^{*} \\
00 \\
00\end{array}$ & $\begin{array}{l}00 \\
02 \\
01\end{array}$ \\
\hline \multirow[t]{2}{*}{2016} & $28^{\circ} \mathrm{C}$ & Control & 30 & 30 & $\begin{array}{l}37,39 \\
41,44 \\
47 \text { ( } 06 \\
\text { each day) }\end{array}$ & 00 & 30 \\
\hline & $31.5^{\circ} \mathrm{C}$ & High Temperature & 15 & 12 & $\begin{array}{l}40 \\
\text { Hatchling }\end{array}$ & $\begin{array}{l}00 \\
05\end{array}$ & $\begin{array}{l}04 \\
03\end{array}$ \\
\hline
\end{tabular}

$239 *$ These embryos were small and equivalent to those at days $30-35$ at $28^{\circ} \mathrm{C}$, the stage at which

240 all the embryos have rudimentary Hemipenis. Presence of $\mathrm{Hp}$ at this stage does not ensure 
242 Table 2 A chart summarising diurnal weather conditions through June and August during the 4 years of

243 study

\begin{tabular}{|c|c|c|c|c|c|c|c|}
\hline $\begin{array}{l}\text { S. } \\
\text { No }\end{array}$ & Year & $\begin{array}{l}\text { Min. Temp. } \\
\text { Range (Av.) }\end{array}$ & $\begin{array}{l}\text { Max. Temp. } \\
\text { Range (Av.) }\end{array}$ & $\begin{array}{l}\text { Fluctuation } \\
\text { diurnal temp. }\end{array}$ & $\begin{array}{l}\text { \% Relative } \\
\text { Humidity }\end{array}$ & $\begin{array}{l}\text { Range Rain- } \\
\text { fall (mm) }\end{array}$ & $\begin{array}{l}\text { Days of } \\
\text { rainfall }\end{array}$ \\
\hline 1 & 2013 & $\begin{array}{l}24.4-28.6 \\
(26.3)\end{array}$ & $\begin{array}{l}29.8-39 \\
(34.1)\end{array}$ & \multirow[t]{4}{*}{$7-10^{\circ} \mathrm{C}$} & $54-100$ & 681.5 & $44 / 92$ \\
\hline 2 & 2014 & $\begin{array}{l}22.9-27.9 \\
(25.7)\end{array}$ & $\begin{array}{l}29.6-39 \\
(34.1)\end{array}$ & & $54-100$ & 573 & $27 / 92$ \\
\hline 3 & 2015 & $\begin{array}{l}25-28.7 \\
(26.8)\end{array}$ & $\begin{array}{l}27.2-38 \\
(33.8)\end{array}$ & & $67-100$ & 768 & $33 / 92$ \\
\hline 4 & 2016 & $\begin{array}{l}24.2-31.9 \\
(27.4)\end{array}$ & $\begin{array}{l}28.2-43 \\
(35.0)\end{array}$ & & $32-100$ & 963.3 & $47 / 92$ \\
\hline
\end{tabular}

246 Figure legend:

Fig. 1 Hematoxylene-stained $7 \mu \mathrm{m}$ thick sections of the gonads of (a) 10 day old hatchling of embryo grown at $28^{\circ} \mathrm{C}$ and (b) 44 day old embryo grown in natural condition. Well developed cortex with large meiocytes is seen in both sections. While there is no medullary remnant in the embryonic gonad (b), atrophied medulla with no sex cords is seen in the hatchling (a). 
1. Hematoxylene-stained $7 \mu \mathrm{m}$ thick sections of the gonads of (a) 10 day old hatchling of embryo grown at $28^{\circ} \mathrm{C}$ and (b) 44 day old embryo grown in natural condition. Well developed cortex with large meiocytes is seen in both sections. While there is no medullary remnant in the embryonic gonad (b), atrophied medulla with no sex cords is seen in the hatchling (a).
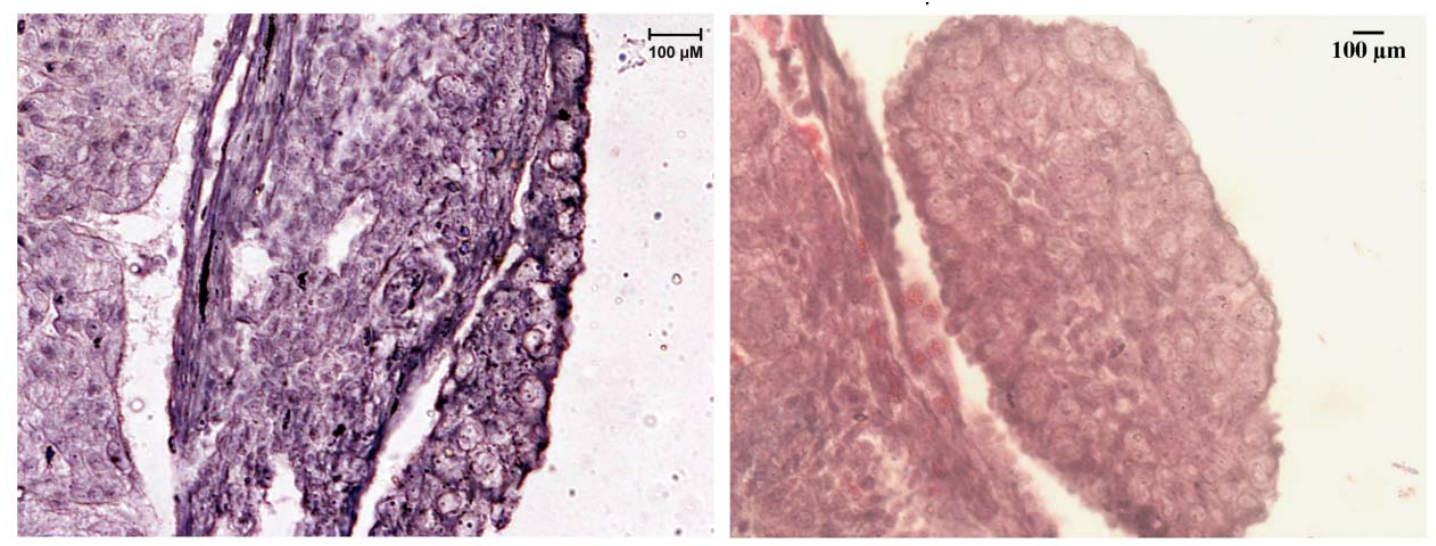